\title{
Conduciveness to Scholarship: The Essence of Academic Library as Place
}

\author{
Karen Antell and Debra Engel
}

\begin{abstract}
The dawn of the Internet era has prompted many researchers to investigate changes in the use of academic libraries, but most studies explore student use, rather than faculty use, of library space. In contrast, this study surveys use of the academic library space among faculty and doctoral students and explores the phenomenological differences between using library space and using the library remotely. The authors hypothesized that older scholars (by age and by "scholarly age," as measured by the year in which the scholar's last academic degree was earned) would report greater use of the physical library and less use of the library's electronic resources and would make more positive statements about the physical space than would younger scholars. In three of the four major themes that emerged from the qualitative survey data, this hypothesis is supported. However, in the fourth theme, "conduciveness to scholarship," the opposite position was supported. Younger scholars were far more likely than older scholars to make statements reflecting the idea that the physical library is a unique place that facilitates the kind of concentration necessary for doing serious scholarly work.
\end{abstract}

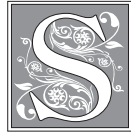

ince the advent of electronic resources and the birth of the Web more than a decade ago, librarians have repeatedly heard the question, "Why do you need a library if everything is available on the Internet?" The simple answer, of course, is, "Not everything is available on the Internet." The more complex answer lies in the synergy created by academic libraries' collections, services, space, staff, and patrons.

Many researchers have already investigated changes in student use of academic library space since the dawn of the Internet era, but few studies explore faculty use of library space. The current study surveys use of the academic library space among faculty and doctoral students and explores the phenomenological differences between using library space and using the library remotely. This work builds on a previous study of faculty study usage, which suggested that many scholars value library spaces simply because when they were "coming of scholarly age" (that is, doing doctoral work), electronic resources did not yet exist. ${ }^{1}$ For them, the library was and remains the place where scholarship happens. Therefore, the researchers hypothesized that a person's age, as well as his or her "scholarly age," would play

Karen Antell is Assistant Professor, Head of Reference and Outreach Services, at University of Oklahoma Libraries; e-mail: kantell@ou.edu. Debra Engel is Associate Professor, Director of Public Services, at University of Oklahoma Libraries; e-mail: dhengel@ou.edu. 
a role in his or her attitudes toward and use of the academic library. (For the purposes of this study, the year in which a person earned his or her highest academic degree serves as a proxy for "scholarly age." That is, those who received their degrees more recently are considered here to be of younger scholarly age than those who received their degrees longer ago.) Specifically, they hypothesized that older scholars (by age and by scholarly age) would report greater use of the physical library and less use of the library's electronic resources and would make more positive statements about the physical space than would younger scholars. The current study explores this issue by means of a survey sent to faculty members and doctoral candidates at the University of Oklahoma Norman campus in June 2004.

\section{Literature Review}

The concept of academic library as place is not new, nor is the debate over academic libraries' relevance. A conference at Harvard in 1949 included papers questioning the future of the library in academic institutions and predicting the demise of the printed book. ${ }^{2}$ These issues still resonate 50 years later. Scott Carlson's controversial 2001 article, "The Deserted Library," ${ }^{3}$ hinted at the death of the academic library-and prompted a passionate response, indicating that the issue is still under intense debate.

"The Deserted Library," which cites decreasing gate counts and circulation rates, did not emerge in a vacuum. Carlson's claims find support in the literature among researchers who believe that the future of the academic library as a physical space is limited. ${ }^{4}$ According to John A. Shuler, spending time in a library is merely a "trip down nostalgia lane"; and, in perhaps the bleakest outlook for academic library buildings, William $\mathrm{H}$. Wisner claims that "we must accept that the historic mission of libraries is finished, that our buildings will disappear gradually over the next 100 years, and that the portable e-book, once perfected, will drive the last nail into our collective coffins." ${ }^{5}$

In direct response to Carlson's article, Mary Reichel and Deanna B. Marcum hosted an online discussion with Carlson in November 2001, titled "Are College Libraries Too Empty?" Although their observations were mostly anecdotal, participants asserted overwhelmingly that academic libraries were bustling with students, and several pointed out that decreasing circulation statistics do not necessarily indicate less library use: "I'm not sure that students are really using libraries less. They use libraries every time they use one of our resources online. They also use the physical facility for collaborative learning and research." 6

Other writers who believe in the academic library's continuing relevance assert that the library building is still essential, but its role in the higher education environment is changing fundamentally to support more educational, collaborative, and social functions while integrating print-based and electronic knowledge. ${ }^{7}$ Frieda Weise notes that the popular image of the library has evolved from a "storehouse" of information to an "active participant in the educational process." 8 Paul Crawford points out that the digital argument is not about an intractable divide between digital libraries and print libraries but rather about the integration of the digital medium with the printed book. ${ }^{9}$ Larry Dowler, Michael Gorman, Walt Crawford, and William A. Gosling also dispute the notion that the library building is living on "borrowed time." 10

Studies and anecdotal reports about new and recently renovated academic library buildings affirm the idea that academic libraries are essential spaces whose roles are evolving. Richard J. Bazillion and Connie L. Braun discuss library design and space planning, exploring the ways in which contemporary academic libraries are changing from collections of printed materials to "participants in the full range of scholarly activity."11 In addition, many 
new and renovated buildings have seen significant increases in use among students and faculty, as well as increased satisfaction reports. ${ }^{12}$

Denise A. Troll challenges academic librarians to evaluate library usage patterns rather than relying on anecdotal data to explain user behavior within the library. ${ }^{13}$ However, precious little actual research exists on this topic. Harold B. Shill and Shawn Tonner find that expanded or new academic library buildings remodeled or built between 1995 and 2002 "provide a vastly improved ambience that encourages use, rather than avoidance, of the library building." 14 In a companion research paper, Shill and Tonner explore the effect of building improvements on 354 academic libraries and find that " 80 percent of the libraries completing a major space improvement project between 1995 and 2002 experienced greater facility usage in 2001-2002."15 These two studies together form a powerful argument that patrons are not "deserting" academic libraries when facilities are new or have recently been renovated.

One factor evaluated by the Association for Research Library's (ARL's) LibQUAL ${ }^{\mathrm{TM}}$ library assessment instrument is "library as place." The 2004 LibQUAL $+{ }^{\mathrm{TM}}$ data indicate a "generation gap" between students and faculty. Interestingly, the generation gap is the opposite of what one might expect: "Survey data do show that the physical library is more important to undergraduates than it is to graduate students and faculty. Twice as many undergraduates as faculty visit the library on a daily basis, and undergraduates consistently give much higher ratings for desired level of service in the 'Library as Place' dimension than faculty do." 16

Debra Engel and Karen Antell report on the use of faculty studies in ARL libraries, finding that these personal spaces within libraries are valued by scholars as being essential to their productivity. ${ }^{17}$ However, scholars interviewed in this study report that their "academic upbringing" was instrumental in developing their habit of working in the library building. This led the researchers to ask whether age is a factor in how scholars use library spaces: "In the future, then, research on faculty information-seeking behaviors, which now focuses almost exclusively on the use of resources, will need to address how the emerging generation of academics uses and values library facilities. If the academic upbringing of younger faculty members does not include the practice of using the resources and space in a library, will faculty spaces soon sit vacant?"18

The current study, described below, attempts to address this question by investigating the role of age and scholarly age in academics' use of library spaces.

\section{Method}

The authors developed a survey consisting of 30 questions in two parts. Part one, with eight questions, requested demographic information about the respondent's age, university status (faculty or doctoral student), gender, academic degrees, research area, and attitude toward technology. Part two, consisting of 22 questions, solicited information about the respondent's use of library spaces at the University of Oklahoma and included questions about whether respondents used the physical space of the library, whether they used electronic resources remotely, how frequently they used the library, how long their typical library visits were, which areas of the library they used, and which activities they engaged in while at the library. Most questions were multiple-choice, but two requested a written response. (The survey is reproduced in the Appendix.) The survey was mounted online, and participation was solicited via an email to all faculty members and doctoral students at the University of Oklahoma, Norman campus, in June 2004. The email contained a link to the anonymous online survey but also offered participants the option of receiving a print survey instead. The email was sent to 1,800 people, and 241 responded, for 
a response rate of 13.4 percent. Of these, only one requested a print survey; 240 responses were made online.

The online survey recorded data in a Microsoft Access database. The quantitative data (from the multiple-choice questions) were exported to SPSS for analysis. The qualitative data (from the narrativeresponse questions) were collected in a Microsoft Access report and subjected to content analysis by the authors. The content analysis revealed the themes that emerged from the participants' narrative responses.

Because the survey response rate $(13.4 \%)$ was low, it is possible that the survey results are biased: those who chose to respond might be a nonrandom sample of the entire group. For instance, it is possible that the online survey format was more appealing to younger people, or that the survey topic prompted responses only in people who are heavy users of library space, or that people in the social sciences are generally more likely to respond to surveys. The possibility of bias must be acknowledged; however, it is impossible to predict the type of bias, if any. The possibility of nonresponse bias exists for all survey instruments, and in general, the lower the response rate, the greater the possibility of bias.

However, the response rate of 13.4 percent, although low, is not unusual for online surveys. For instance, ARL recommends that academic libraries undertaking the LibQUAL $+^{\mathrm{TM}}$ survey target a response rate of about 15 percent: " $15-20 \%$ is considered a good response rate for a web-based survey." 19 Other evidence suggests that response rates of
10 to 28 percent are acceptable and are commonly found in published survey results in the social sciences. ${ }^{20}$ Therefore, the response rate of 13.4 percent obtained in this survey, if not as high as might be hoped, appears to be acceptable according to the standards of similar recently published survey results.

\section{Quantitative Results}

Although the survey collected data about respondents' gender, academic discipline, and other demographic features, this particular study focuses on whether age and scholarly age are factors in respondents' use of library space. Therefore, age and scholarly age are the only factors examined in this paper; the other factors, although possibly relevant to an overall understanding of academics' use of library space, are beyond the scope of this study.

The quantitative data were examined by age and scholarly age using the following increments:

- Age: measured by year born, from the 1940 s to the 1980 s in ten-year increments.

- Scholarly age: measured by year in which the latest academic degree was earned, from the 1970s to the 2000s in tenyear increments. (Only three respondents reported having graduated before 1970, so it was not possible to draw inferences about pre-1970 graduates as a group.)

Due to the survey's length, it is not possible to report on the responses to each question. Instead, this section reports on the most striking quantitative results-results that show major differences in patterns of library use among re-

\begin{tabular}{|c|c|c|c|c|c|c|c|c|c|c|c|}
\hline \multicolumn{12}{|c|}{$\begin{array}{c}\text { FIGURE } 1 \\
\text { Number of Respondents in Each Age Group and Each Scholarly Age Group }\end{array}$} \\
\hline \multicolumn{6}{|c|}{ Age: born in the ... } & \multicolumn{6}{|c|}{ Scholarly age: last degree earned in the ... } \\
\hline $1940 s$ & 1950s & $1960 \mathrm{~s}$ & 1970s & $1980 \mathrm{~s}$ & $\begin{array}{c}\text { No } \\
\text { response }\end{array}$ & $\begin{array}{l}\text { Before } \\
\text { 1970* }\end{array}$ & 1970s & $1980 \mathrm{~s}$ & $1990 \mathrm{~s}$ & $2000 s$ & $\begin{array}{c}\text { No } \\
\text { response }\end{array}$ \\
\hline 6 & 73 & 58 & 86 & 13 & 5 & 3 & 26 & 30 & 71 & 105 & 6 \\
\hline
\end{tabular}




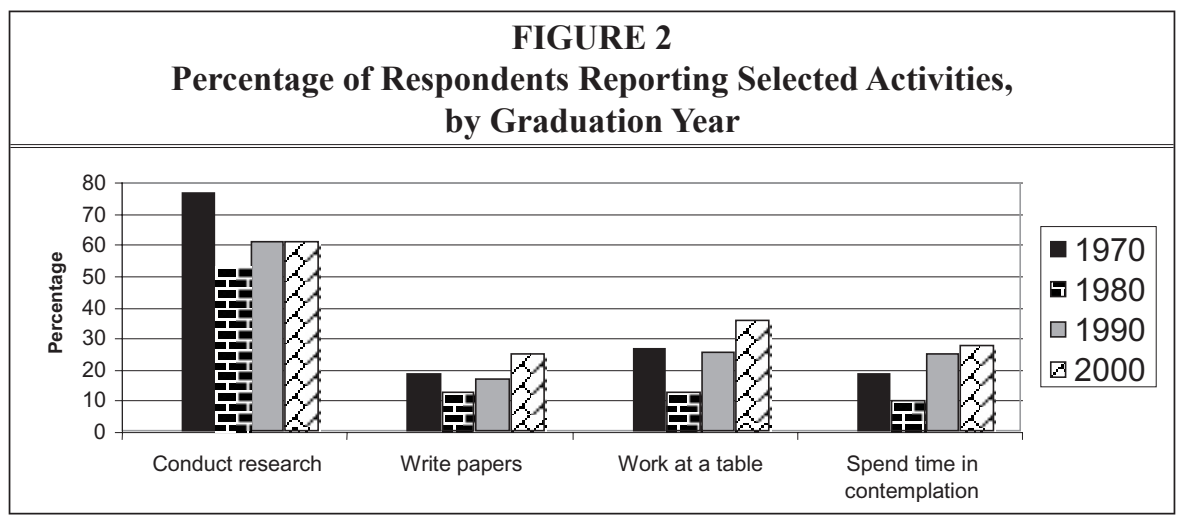

spondents of different ages and scholarly ages. The number of respondents in each age and scholarly age group is shown in figure 1.

The responses indicate that the majority of scholars of all ages and scholarly ages conduct research in the library. However, this percentage decreases steadily from a high of 77 percent for those who graduated in the 1970s to 61 percent for respondents who graduated after 1990. In contrast, using library space for writing papers appears to be increasing among younger generations of scholars: The percentage of scholars who report writing papers in the library more than doubles from 14 percent of respondents born in the 1940s to 31 percent of respondents born in the 1980s. Results show a similar but less dramatic increase when the respondents are grouped by scholarly age: The most recent graduates are the group with the highest percentage reporting writing papers in the library. (See figures 2 and 3.)

The percentage of respondents who report working at a table in the library more than doubles from 19 percent of the respondents born in the 1940s to 39 percent of the respondents born in the 1980s. When viewed by scholarly age, this usage also shows an interesting pattern: At least twice as many respondents in the earliest graduation group and the two latest graduation groups report working at tables as do those who graduated in the middle years.

In addition, more younger respondents than older respondents report spending time in contemplation in the library. Of those born in the 1940s, 14 percent report that they spend time in contemplation in the library, as opposed to 33 percent of those born in the 1960s and 31 percent of those born in the 1980s. Results are similar when viewed by respondents' scholarly

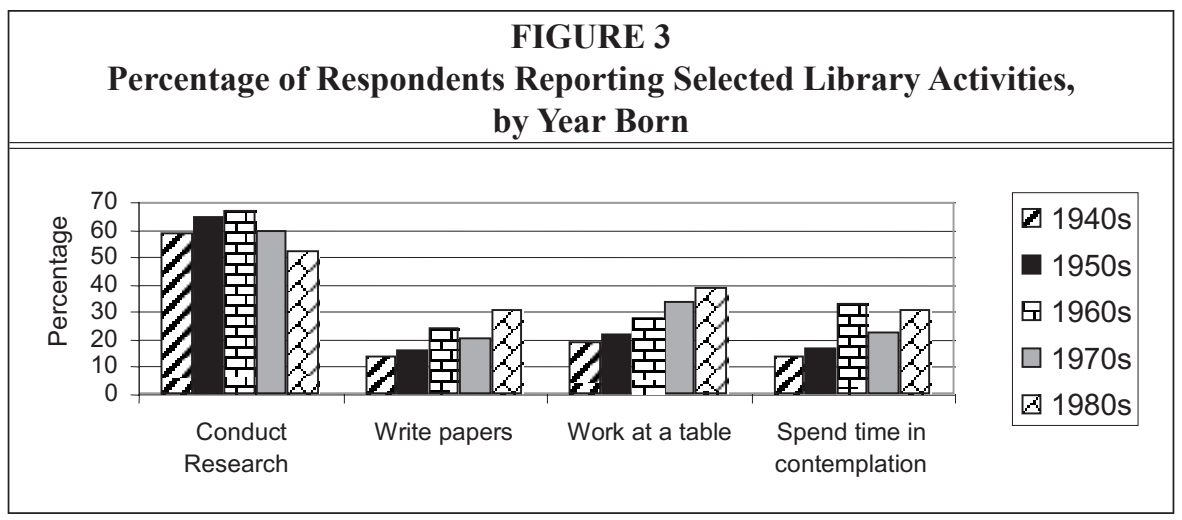




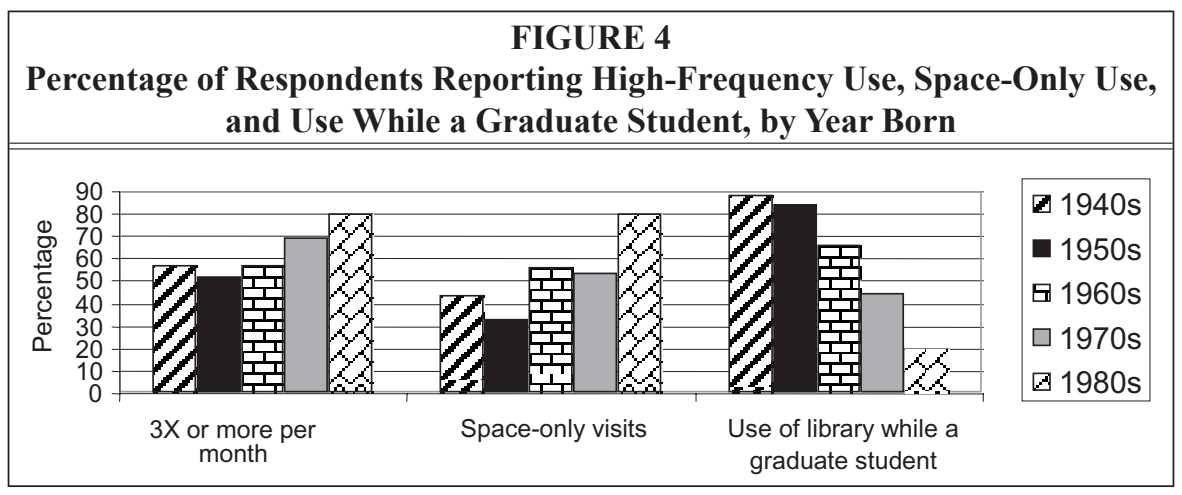

age: 10 percent of 1980s graduates report spending time in contemplation in the library, as compared to 28 percent of 2000 s graduates.

For the purposes of this study, highfrequency library users are defined to be those who use the library three times or more per month. Eighty percent of the youngest scholars (born in the 1980s) are high-frequency users; this is the highest percentage of any age group. When examined by scholarly age, the results support this finding: A consistently high percentage of respondents from all graduation years are high-frequency library users, but the most recent graduates show the highest percentage of high-frequency users. (See figures 4 and 5.)

Respondents also were asked whether they ever used the physical space of the library for study, work, or relaxation without using library resources (books, journals, computers, etc.) during their visit. For the sake of simplicity, this will be termed the "space-only" visit. The percentage of respondents reporting space-only visits increases dramatically among the younger groups: 44 percent of those born in the 1940s indicate that they make space-only visits, and this percentage increases to 80 percent of those born in the 1980s. Viewing the results by graduation year rather than age reinforces this pattern: 39 percent of the respondents who graduated in the 1970s indicate that they make space-only visits, increasing to 56 percent of the respondents who graduated after the year 2000 .

Several of the questions in the survey asked the respondents to report on their

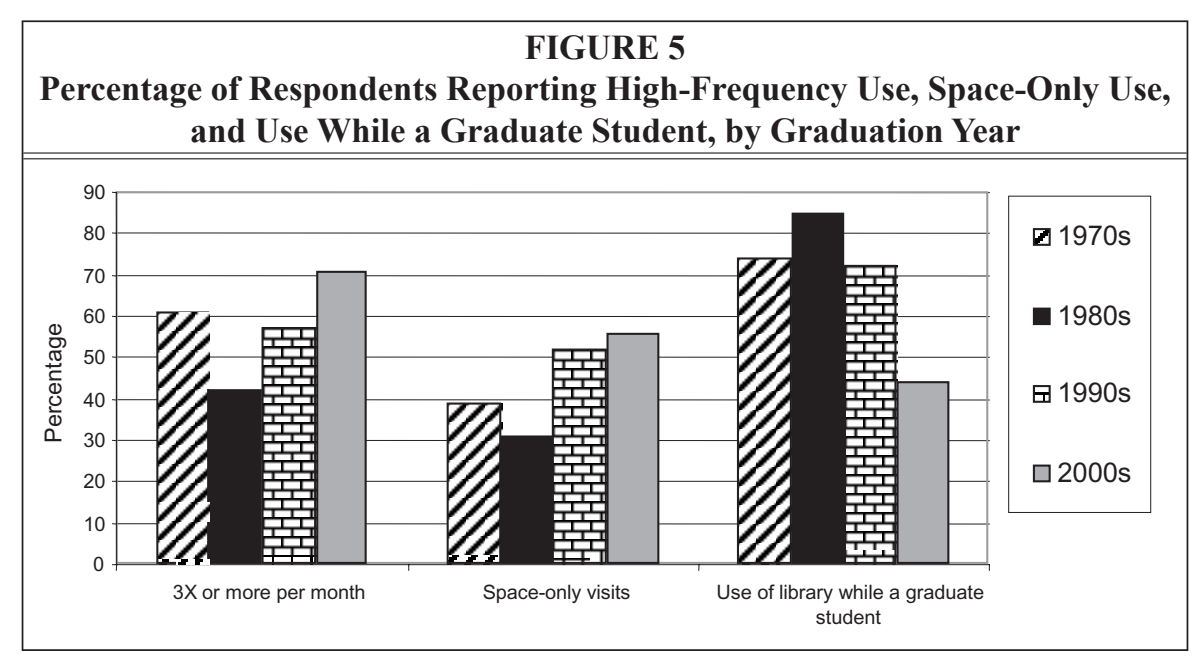


library usage during their graduate school days, the time when they were "coming of scholarly age." Library use during graduate school shows a marked decline among the younger generations of scholars. Although 88 percent of the respondents born in the 1940s report that they conducted research in the library when they were in graduate school, this figure plummets to 20 percent of those born in the 1980s. This dramatic decrease is reinforced when the data are viewed by scholarly age: 74 percent of 1970s graduates report that they conducted research in the library when they were in graduate school, as opposed to only 44 percent of 2000 s graduates.

\section{Qualitative Results}

The survey yielded qualitative as well as quantitative results. Two questions asked participants for comments:

- In your opinion, are there differences between using the library remotely (using electronic resources via the Web site) and using the library's physical space? If so, what are the differences?

- If you have any other observations about your use of library space that you would like to share, please use the space below.

Of the 241 respondents, 176 (73\%) provided answers to one or both of these questions. These 176 people made a total of 390 statements in their narrative responses. Analysis of the 390 statements reveals the major themes expressed in the responses. Each author coded the responses independently to help ensure reliability.

The researchers identified eleven themes in the qualitative data, including four "major" themes that each account for more than 10 percent of the total responses (and together account for 73.5\% of all responses). The remaining seven themes, each with less than 10 percent of the total responses (and together accounting for $26.5 \%$ of responses), are categorized as minor themes. These themes are discussed below in descending order of significance.

\section{Major themes}

\section{Convenience-electronic resources}

(97 responses; $24.8 \%$ of total.) This theme encompasses statements indicating the belief that using the library electronically is convenient.

- "I am a computer person and I enjoy the electronic interaction and the variety of resources available via the web."

- "Remotely is more convenient."

- "I would prefer an entirely electronic library."

In many cases, respondents qualified their statements in this category with "but" clauses:

- "The electronic search functions are an amazing development, but a significant portion of the science literature that I need is not yet available digitally."

In such cases, the first statement was coded as "Convenience-electronic resources" and the second statement was coded to its appropriate theme-in this case, "Comprehensiveness - physical library" (see below).

\section{Browsability—physical library}

(73 responses; $18.7 \%$ of total.) This category covers responses conveying the idea that the physical library facilitates browsing. Also included in this category are responses that praise the physical library's organization or that indicate the respondent's preference for engaging with information tactilely.

- "The subject organization of the library facilitates finding useful material that I may not have come across when searching online."

- "I pay more attention when I hold the actual book in my hands rather than paging through a virtual representation of it."

\section{Conduciveness to scholarship-physical library}

(60 responses; $15.4 \%$ of total.) This category encompasses statements expressing the sentiment that the physical library is conducive to doing scholarly work. Statements in this category touched on many 
ideas, such as the library's "role" as a place for concentration and focused work, the library's silence and sense of "sanctuary," and the notion of truly engaging in one's work by "dialoging" with the books' authors-communicating across the ages, as it were.

- "I appreciate the level of concentration I am able to achieve in that setting."

- "I dialogue with the authors by photocopying and making margin notes (no, I do not write in the books!)"

\section{Comprehensiveness-physical library}

(57 responses; $14.6 \%$ of total.) Statements in this category express the idea that the physical library's collection is more comprehensive, more current, or more permanent than the electronic collections.

- "When I am in the library, I have more access to information-not every journal or book can be obtained electronically."

- "The most important role of the library is to deposit materials, especially professional journals, without gaps in subscription - and this cannot be guaranteed by web access."

\section{Minor themes}

\section{Pleasure-physical library}

(29 responses; $7.4 \%$ of total.) Statements in this category include comments about the physical library's subjective appeal. Respondents report that the physical library gives them pleasure in a variety of ways-aesthetically, socially, and intellectually.

- "It's much more relaxing to work in the Great Reading Room than in my office."

- "The History of Science collection is a real treat to physically visit."

\section{Convenience-physical library}

(22 responses; $5.6 \%$ of total.) Although "Convenience-electronic resources" is by far the dominant theme in the qualitative responses, a notable minority of statements mention the physical library's convenience. These statements focus mainly on the convenience of staff assistance, but ease of access and portability also are cited.

- "Using the library staff is almost always faster than performing the same tasks online."

- "The electronic resources are not as logically organized - this can be frustrating and may take longer than looking for things the old-fashioned way."

\section{Readability-physical library}

(21 responses; $5.4 \%$ of total). Responses in this theme indicate that physical materials are easier to read than on-screen information.

- "In-hand scanning of books is much more helpful than attempting to search through pages of info on a computer."

- "I seriously doubt that many people are capable of reading mathematics journal articles via computer - these require pencil, paper, and long hours of work."

\section{Narrow search/wide search}

(15 responses; $3.8 \%$ of total.) This category encompasses comments that reflect the distinction between doing a targeted search for a specific piece of information and doing an exploratory search to scan a field or topic.

- "For a targeted search, electronic access is better - for browsing and collecting ideas, the physical space is better."

- "While certain bibliographic work can be done easily online, the ability to browse journals in addition to looking at a targeted article is best done in the library."

\section{Library as symbol}

(11 responses; $2.8 \%$ of total.) Statements in this category indicate the physical library's value as a symbol rather than its direct usefulness to scholarly work.

- "The physical library is a very important part of academic tradition, and the hard copy book is a symbol."

- "In my mind, the size and organization of a library are reflective of the university as a whole." 


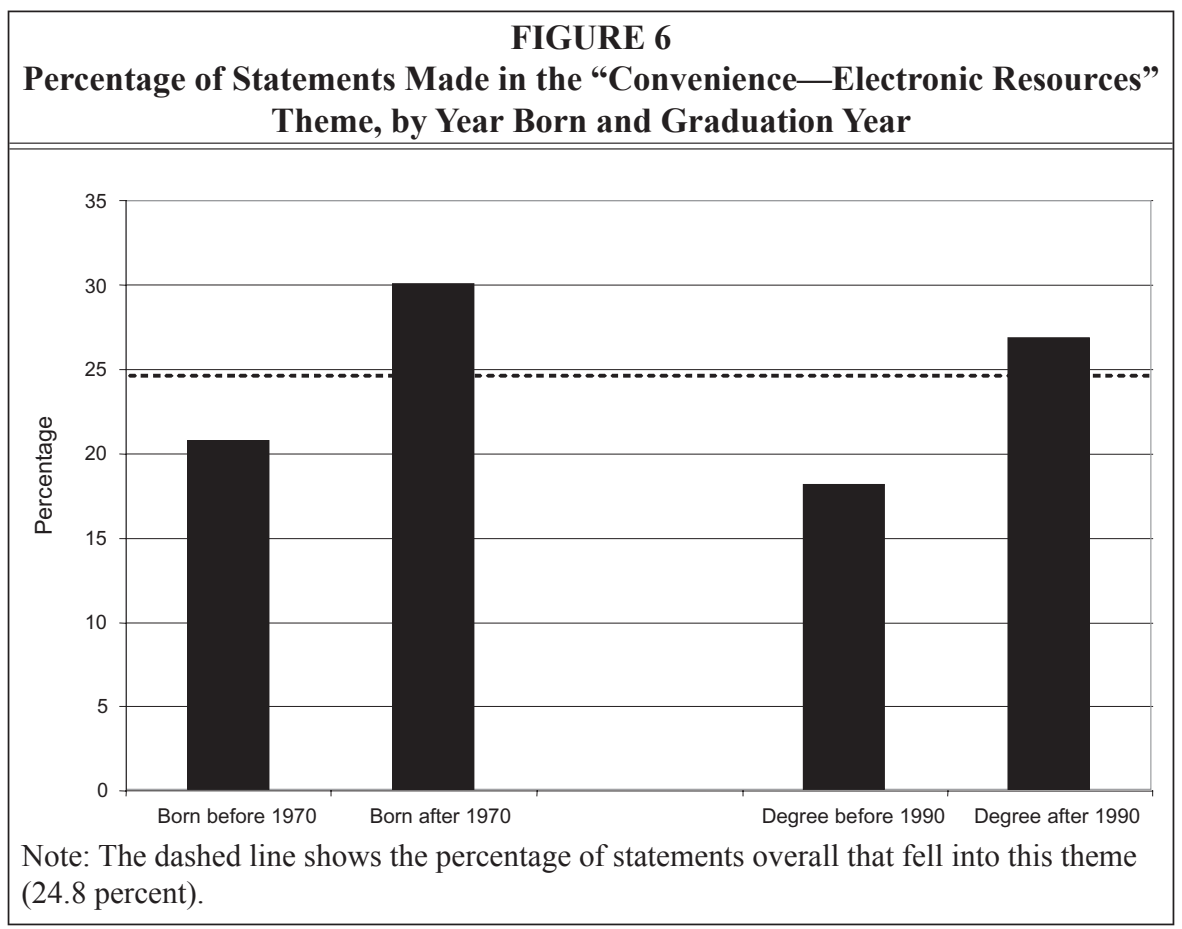

\section{Readability - electronic resources}

(3 responses; $0.7 \%$ of total.) This small category includes those few statements from people who prefer reading electronic materials to physical books.

- “Journal articles appear cleaner when downloaded than when copied from the journal in the library - I always get electronic versions before I try the physical spaces."

\section{Browsability - electronic resources}

(2 responses; $0.5 \%$ of total.) Although most of the responses that mention browsability indicate that the physical library is easier to browse (see "Browsability-physical library," above), two responses indicate a preference for browsing electronic resources.

- "Online journal databases such as JSTOR and Project Muse are superior to going through the paper copies at the library."

\section{Discussion}

The four major themes identified in the qualitative data are reflected in the quantitative survey results as well. For this reason, this discussion will use these four themes as a focal point to integrate both types of data.

\section{Convenience-electronic resources}

Overall, the convenience of electronic access to library resources is by far the most important theme that emerges from the qualitative responses: 24.8 percent of the participants' statements reflect this theme. This is perhaps not surprising: For at least the last decade, librarians have heard their patrons' praise for electronic access and their call for ever more resources to be made available online.

However, when these results are examined by respondents' age and scholarly age (see figure 6), it can be seen that the convenience of electronic resources is more important to younger respondents. For people born after 1970, and for those who received their last degree after 1990, electronic convenience is more important than for older people and pre-1990 gradu- 
ates. Although "Convenience-electronic resources" statements account for 24.8 percent of all statements, for people born after 1970, this theme represents 30.1 percent of all statements, whereas for people born before 1970, this theme represents 22.9 percent. Similarly, 26.9 percent of post-1990 graduates' statements fall into the "Convenience-electronic resources" theme, as compared with 18.1 percent of pre-1990 graduates' statements. Again, this is not surprising, given that younger people and those who have received degrees more recently are the groups that have "come of scholarly age" during the Internet era.

Some of the quantitative data appear indirectly to support this trend. (See figures 7 and 8.) For instance, fewer people in the younger groups report that, when conducting research, they use the physical library space. ${ }^{21}$ Although not conclusive, this indicates that younger people may rely more heavily than older people on electronic resources. The youngest group of respondents, those born after 1980, also shows a sharp decrease in using the library to check out books. The same holds true for several other measures of physical library usage: Younger respondents report less browsing of new books, less use of periodicals, and less use of graduate study carrels. In addition, the use of the physical library space for conducting graduate research and writing dissertations plummets sharply by age: Of the respondents born in the 1940s, 88 percent report that, when they were in graduate school, they did some of their graduate research in the library, and 44 percent report having written part or all of their dissertations in the library. These figures fall with successively younger groups, and for the youngest group, these figures are 20 percent and 10 percent respectively. This trend is similar, but not as dramatic, when respondents are grouped by graduation year. For this theme, then, age and scholarly age appear to be factors affecting scholars' use of library space: Younger scholars value the convenience of electronic resources a great deal more than older scholars do.

\section{Browsability - physical library}

The physical library's browsability, mentioned in 18.7 percent of the qualitative responses, is the second most important theme that emerges from the qualita-

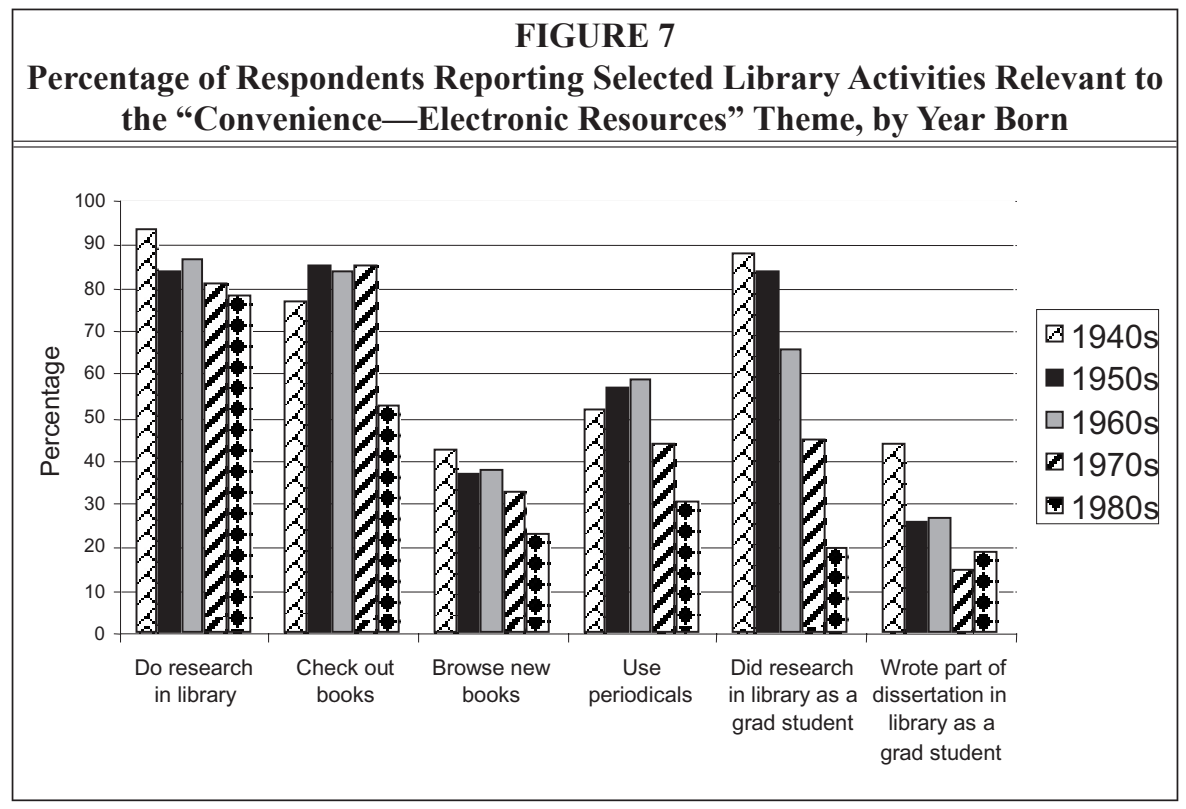




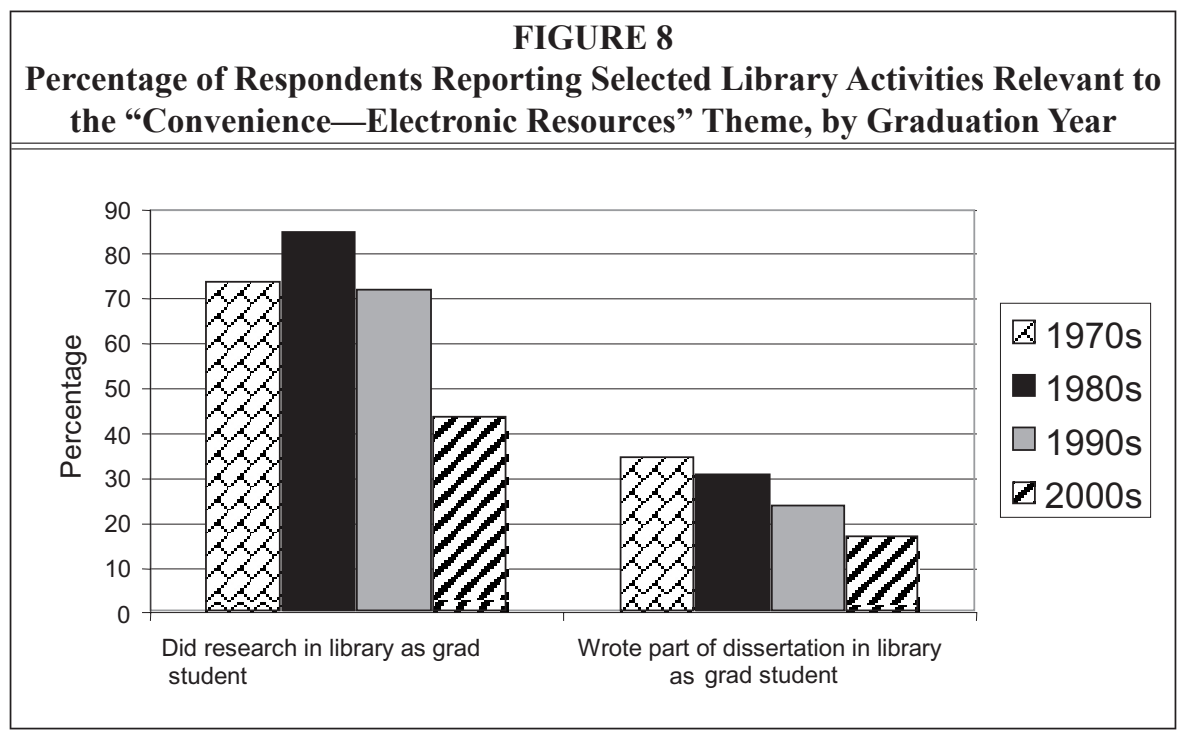

tive findings. This is interesting in itself, because it belies the common perception among librarians that library users prefer to access everything electronically and do not understand the value of the physical collection and its ingenious organization.
However, the results show that browsing the physical library is of somewhat greater value to older people and less recent graduates. (See figure 9.) For respondents born before 1970, "Browsability-physical library" statements account

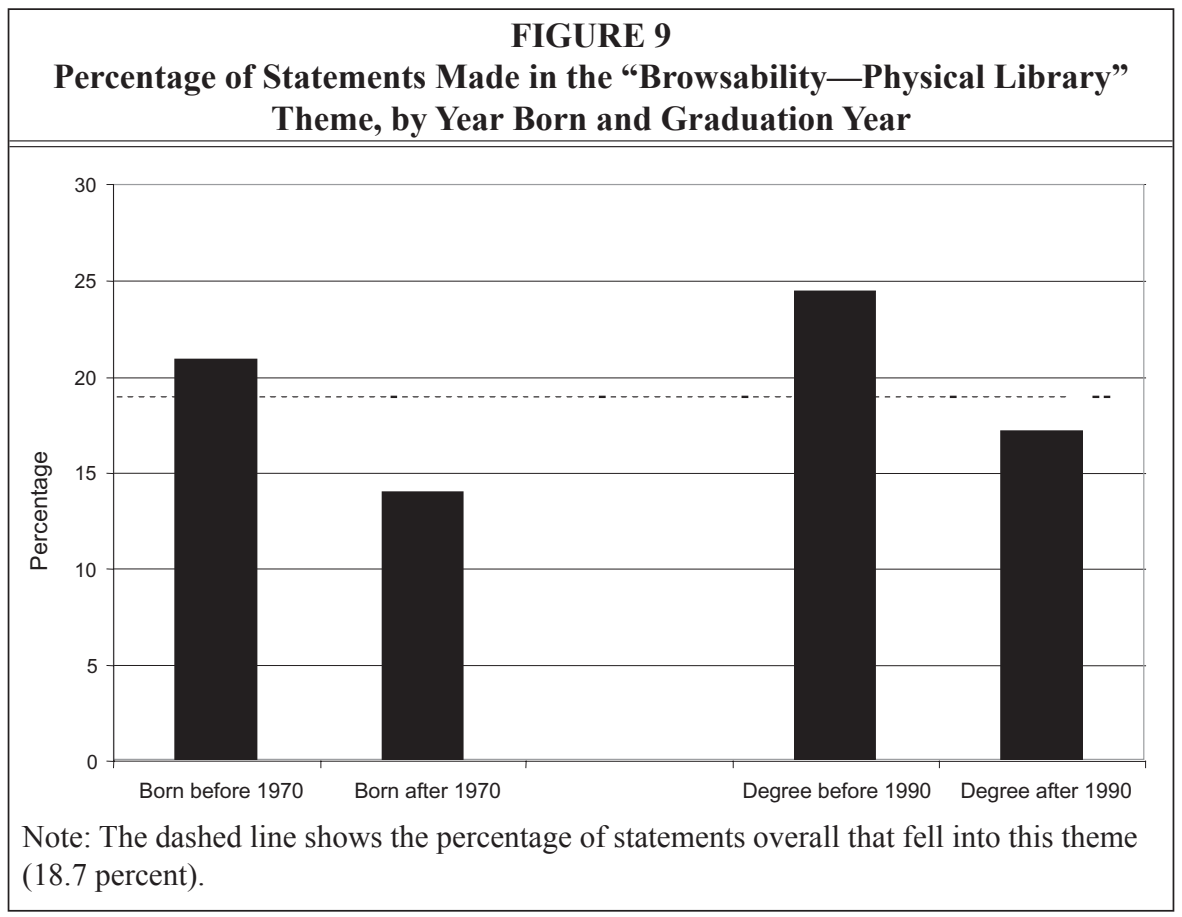




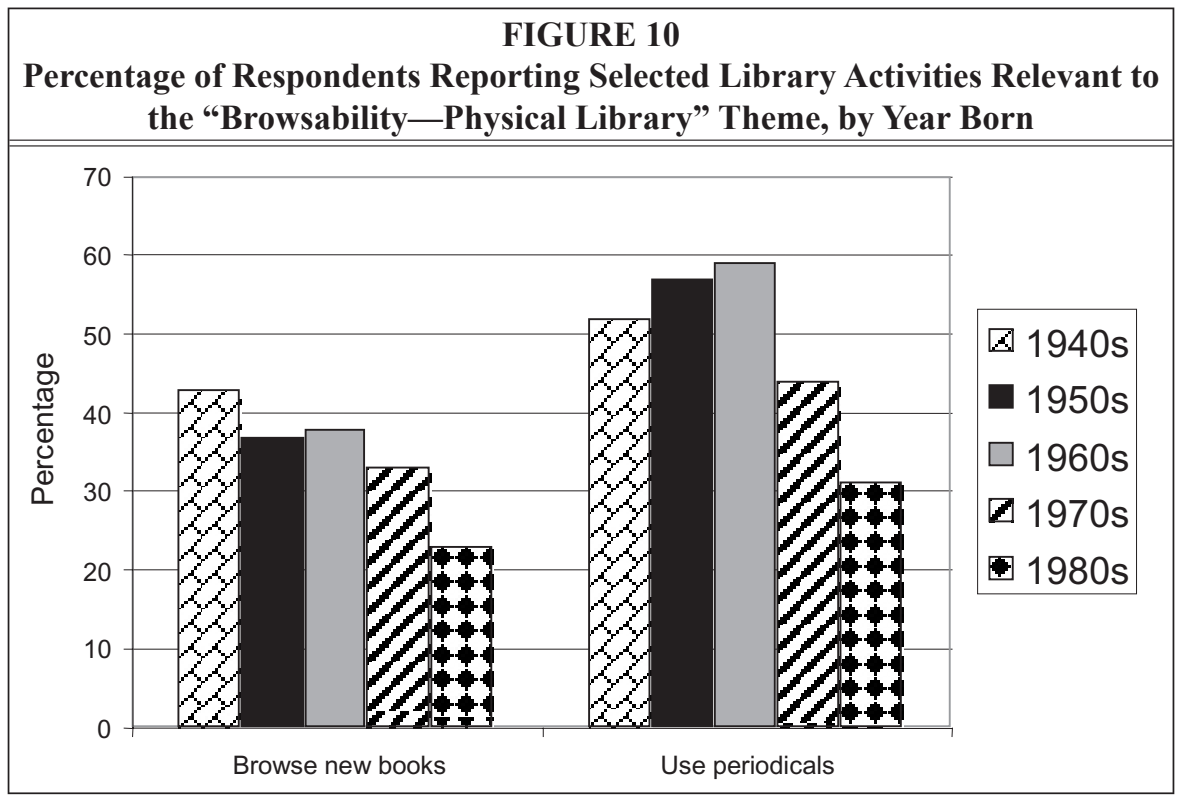

for 20.9 percent of responses; for those born after 1970, this theme accounts for just 14.0 percent of responses. Likewise, for respondents who graduated before 1990, the "Browsability-physical library" theme is reflected in 24.5 percent of responses; for post-1990 graduates, this theme accounts for 17.2 percent of responses.

Although just a few questions in the survey addressed browsing behavior, the quantitative data support this trend as well. (See figures 10 and 11.) The percentage of respondents who report browsing new books increases notably by age, from 23 percent of those born in the 1980s to 43 percent of those born in the 1940s. When examined by scholarly age, this trend is similar but less marked. The use of periodicals shows a similar increase with age (from 31 percent of those born

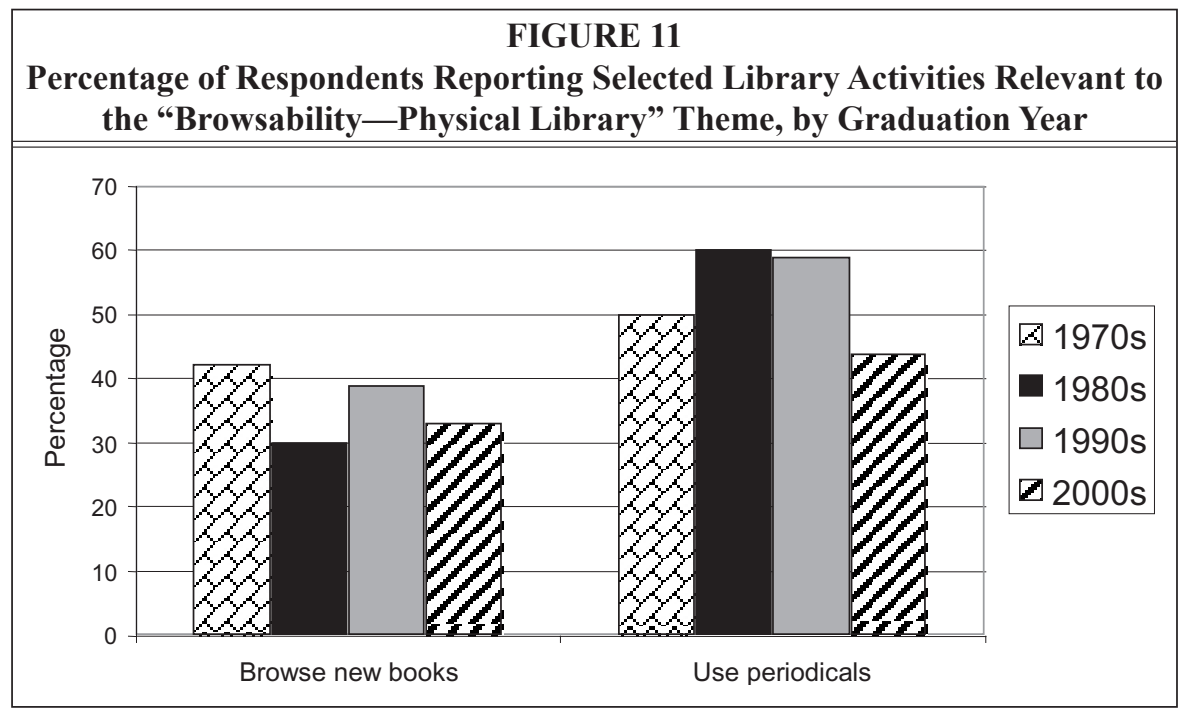




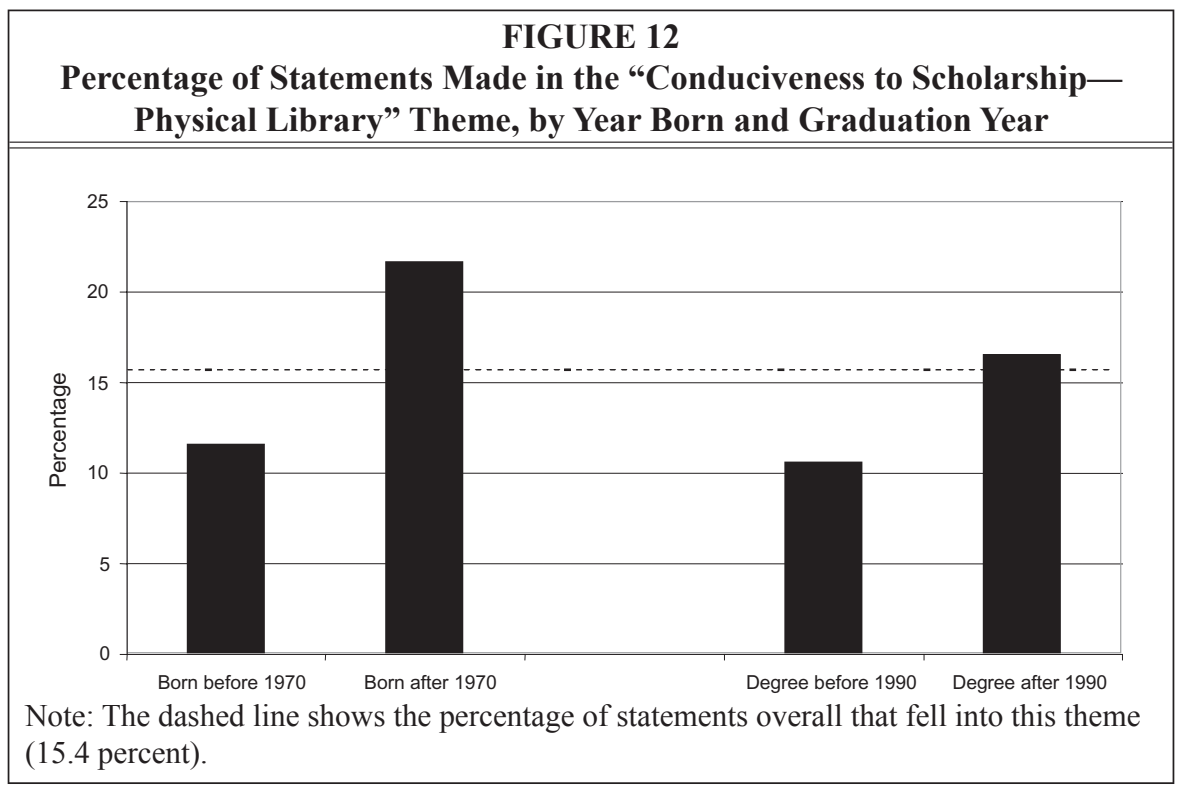

in the 1980s to 52 percent of those born in the 1940s) and graduation year (from 44 percent of post-2000 graduates to 60 percent of 1980s graduates), although it is not necessarily the case that periodical use is a measure of "browsing" behavior in the physical library. (Some periodical use is probably "browsing" behavior, whereas some is more targeted information retrieval.) Thus, age and scholarly age seem to be essential factors that affect how much scholars value the physical library's browsability.

\section{Conduciveness to scholarship—physical library}

The physical library's conduciveness to scholarship, mentioned in 15.4 percent of responses, is the third major theme that emerges from the qualitative data, indicating that library users continue to value the physical library as a place to do scholarly work. (See figure 12.) Most interesting, younger people and more recent graduates appear to care more about conduciveness to scholarship than older people and less recent graduates. Even though 15.4 percent of all responses fall into this category, striking differences emerge when respondents are grouped by age and scholarly age. For people born after 1970, 21.7 percent of responses are about conduciveness to scholarship, as compared to just 11.6 percent of older people's responses. Likewise, for post1990 graduates, 16.6 percent of responses fall into this theme, compared with 10.6 percent of pre-1990 graduates' responses. Because the "conduciveness to scholarship" theme reflects the value of "place" rather than the value of library materials (see "Qualitative Results," above), these results reveal a very surprising trend: The value of "library as place" appears to be appreciably greater among younger library users.

Many questions asked in the survey reflect indirectly on the "conduciveness to scholarship" theme, and, for the most part, the quantitative data support the qualitative results. (See figures 13 and 14.) For instance, the survey shows that younger users and more recent graduates report higher levels of the following activities than older users and less recent graduates:

- work at a library table

- spend time in contemplation at the library

- take a briefcase or backpack to the library 
- take personal books or library books to the library

- take food or drink to the library

- make frequent library visits (three times per month or more)

- make long library visits (one hour or more)

- use a study carrel

- use group study rooms

- make space-only visits to the library

None of these questions asks explicitly "Do you value the physical library's conduciveness to scholarship?" - naturally, the researchers could not design the survey to ask this question, because they could not know in advance that this theme would emerge from the qualitative responses. However, the questions listed above measure several factors that point to the "conduciveness to scholarship" theme: length and frequency of library visits, incidence of space-only library visits, and prevalence of "settling in" behaviors. For instance, taking books to the library, taking food and drink to the library, and using group study rooms all indicate some level of "settling in" to work for extended periods of time. Moreover, they all are behaviors that are consistent with the space-only visit, in which a library user visits the library for reasons other than using library materials or technology-often for intangible reasons, as one respondent notes: "I appreciate the level of concentration I am able to achieve" [at the library].

Although the results of most of the relevant survey questions support the qualitative finding that younger people and more recent graduates value the physical library's conduciveness to scholarship more than older people and less recent graduates do, a few of the relevant questions elicited responses that are highly inconsistent with the qualitative results. For instance, younger people and more recent graduates are less likely than older people and less recent graduates to use faculty studies, to report having used a graduate student carrel during graduate school, and to report having done graduate research or written any part of a dissertation in the library. (See figures 13 and 14.) Because faculty studies are popular and OU Libraries maintains a waiting list for them, one explanation for younger respondents' lower rate of faculty study use might be simply that

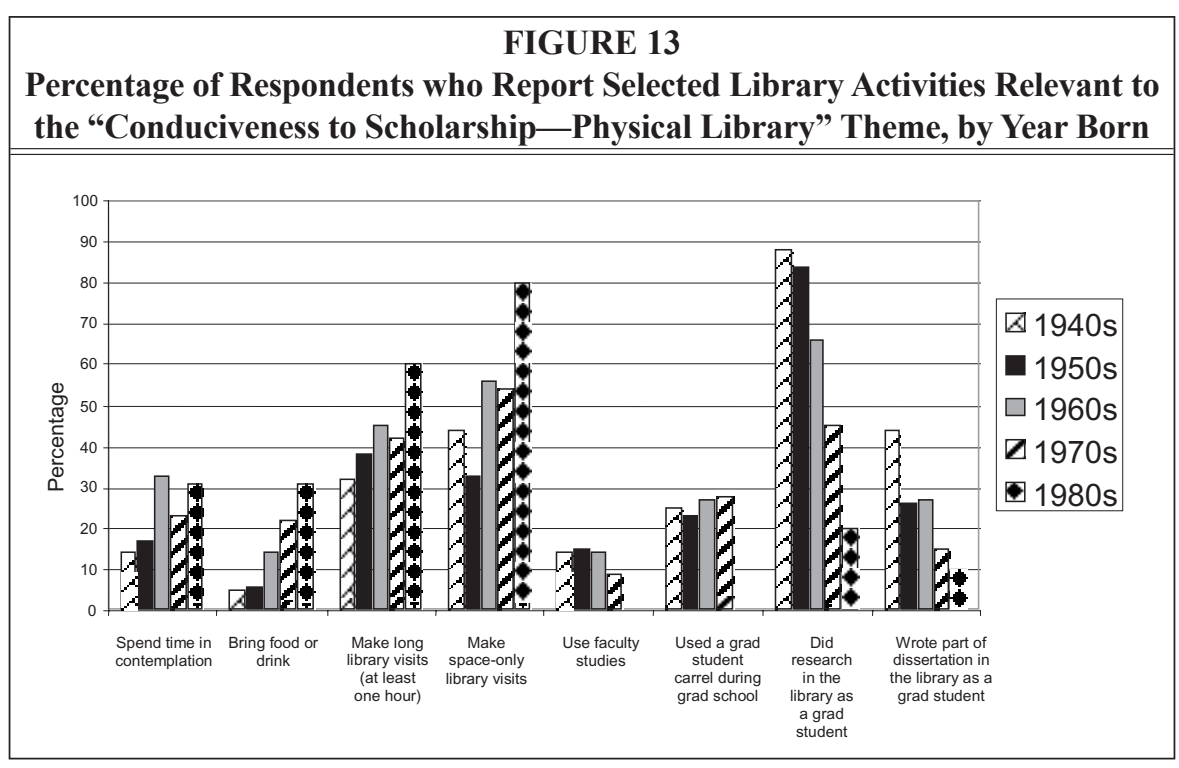




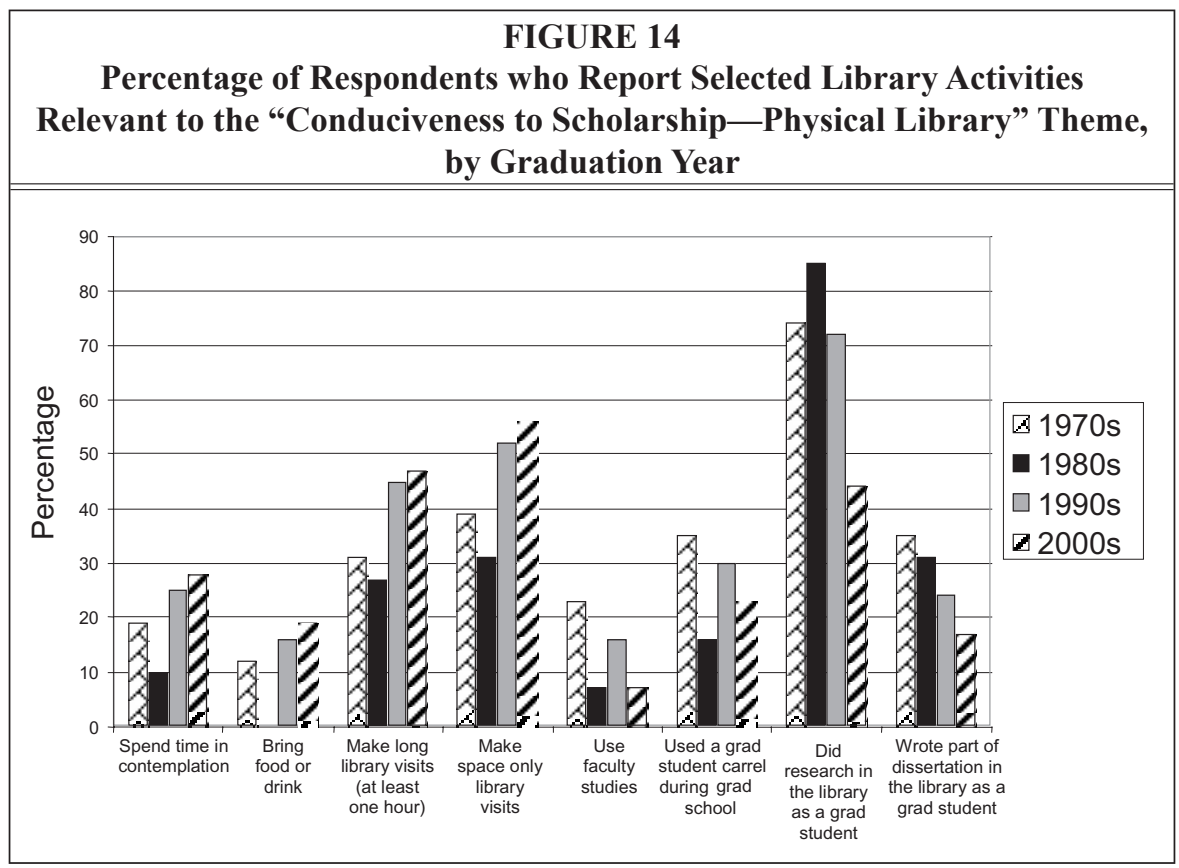

they do not yet have the seniority to have reached the top of the waiting list. However, this cannot explain their lower rate of graduate carrel use or their lower incidence of library use for research activity and dissertation writing. This is simply an inconsistency that the researchers cannot explain: Based on the qualitative findings and most of the relevant quantitative findings, younger people and more recent graduates appear to value greatly the physical library's conduciveness to scholarship, even though their responses to the questions about their library usage as graduate students indicates less use of library space.

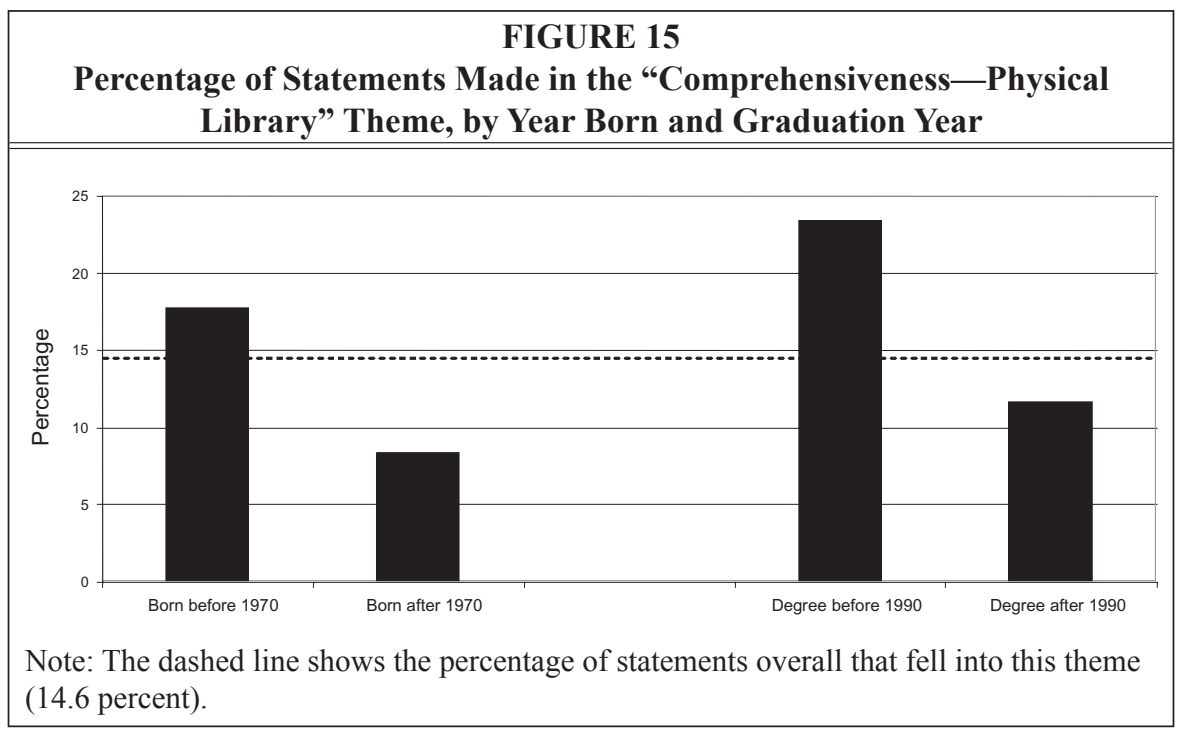




\section{Comprehensiveness-physical library}

The fourth major theme that emerges from the qualitative responses is "Comprehensiveness - physical library," which encompasses statements indicating that the physical library has more comprehensive resources than the electronic collections do. This category comprises 14.6 percent of the qualitative statements overall. When respondents are grouped by age and scholarly age, striking differences emerge. (See figure 15.) For people born before 1970, the "Comprehensiveness-physical library" theme accounts for 17.8 percent of responses, more than twice the percentage for those born after 1970 (8.4\%). Likewise, for pre-1990 graduates, 23.4 percent of responses fall into this theme, as compared with just 11.7 percent of responses by post-1990 graduates.

Responses to survey questions addressing materials usage support the qualitative finding that older people value the physical library's comprehensiveness considerably more than younger people do. For instance, fewer younger people than older people report checking books out of the library, using microforms, using library materials, placing materials on reserve, browsing new books, and using periodicals. (See figure 16.) However, when respondents are compared by scholarly age group, the results are reversed: the more recent graduates are those who report higher levels of these activities. (See figure 17.) So, even though age and scholarly age are both essential factors that are strongly associated with respondents' qualitative statements about the physical library's comprehensiveness, this finding is supported in the quantitative results only for age; for scholarly age, the quantitative results contradict the qualitative results.

\section{Conclusion}

In most ways, the survey findings support the researchers' hypothesis that older scholars (by age and by scholarly age) would report greater use of the physical library and less use of the library's electronic resources and would make more positive statements about the physical space than would younger scholars. In three of the four major themes that emerged from the qualitative data, older scholars' statements reflect this hypoth-

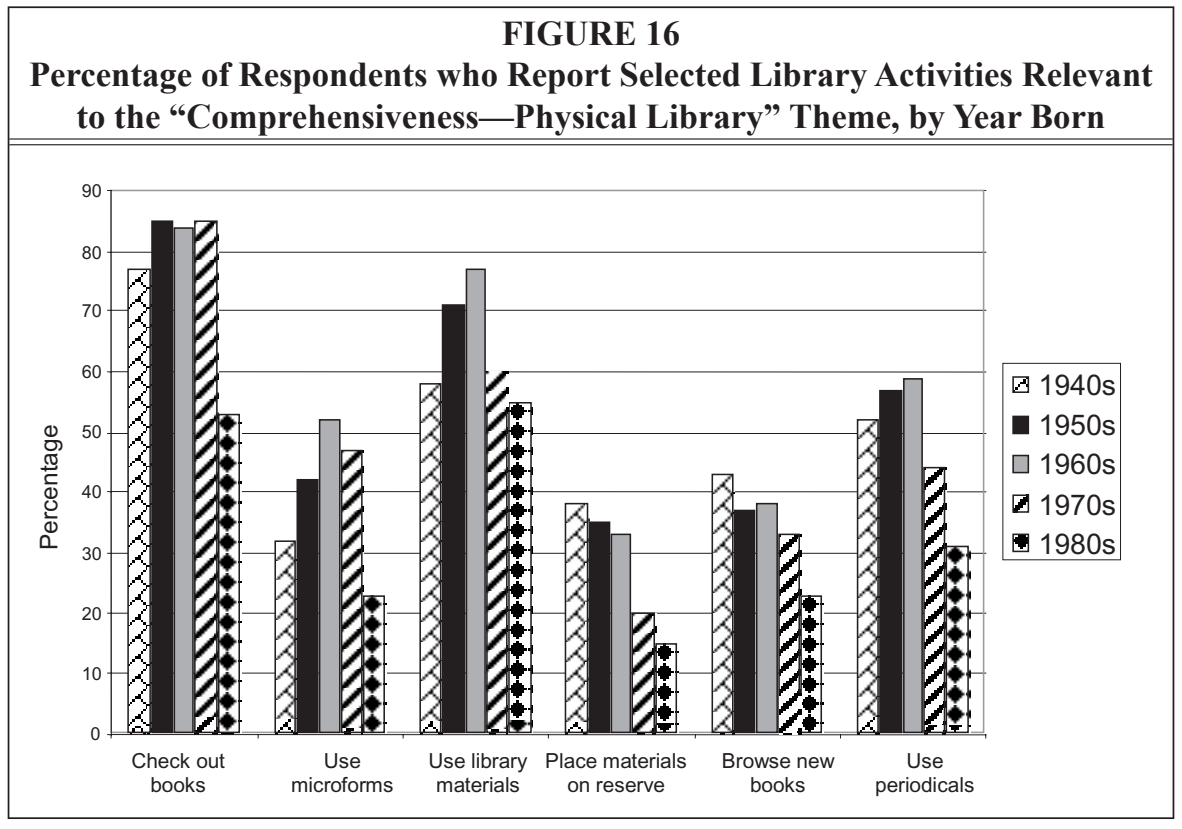




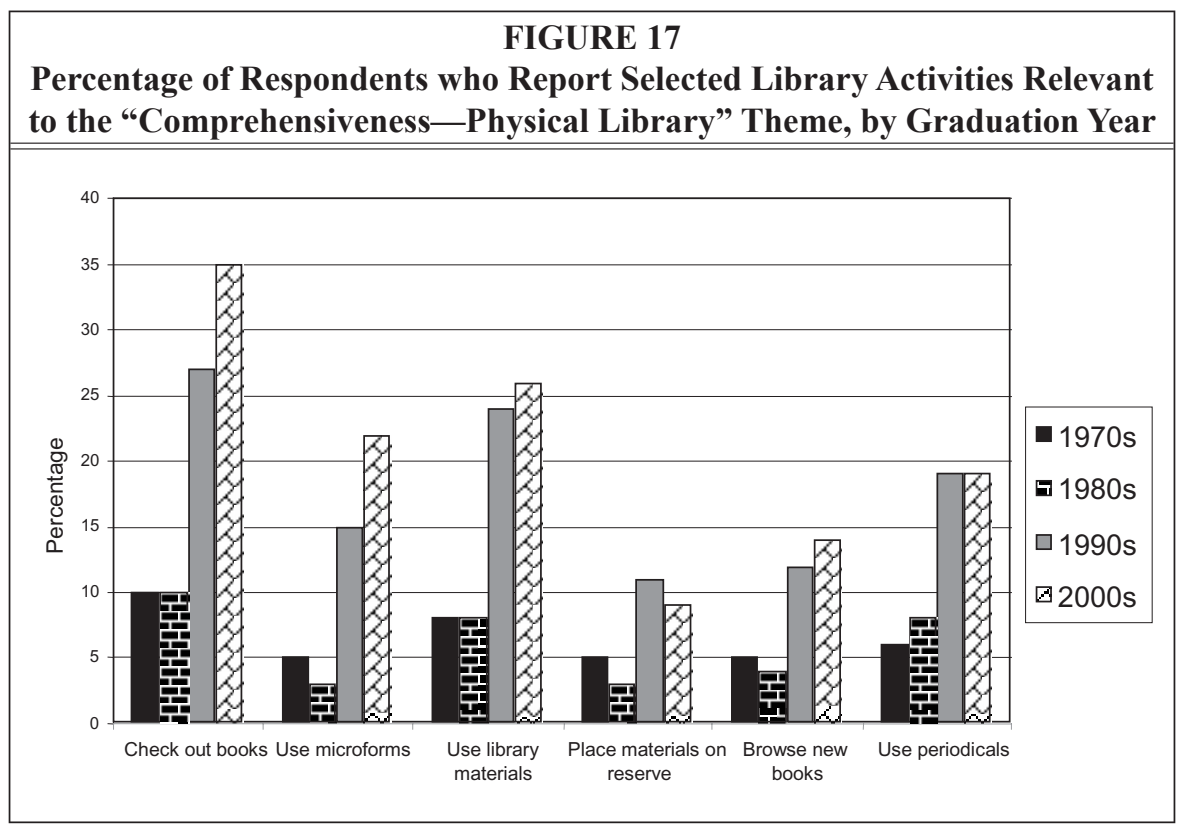

esis. The convenience of electronic resources, while valuable to respondents of all ages and scholarly ages, was found to be considerably more valuable to younger scholars. Likewise, the physical library's browsability and comprehensiveness were found to be considerably more valuable to older scholars.

However, the results in the category "Conduciveness to scholarship-physical library" are rather unexpected. In this one category, the researchers' hypothesis was turned completely on its head: Younger scholars were found to be far more likely than older scholars to make statements reflecting the idea that the physical library is a unique place that facilitates the kind of concentration necessary for doing serious scholarly work. In the words of one respondent, a 2004 graduate, "The physical space of the library is very conducive to intellectual idea development. It can be a nice escape from normal routines. It is the perfect place to go to concentrate." Interestingly, the "conduciveness to scholarship" theme is unlike the other three in that it addresses the value of place quite apart from the value of physi- cal or electronic library materials. So, in a sense, "conduciveness to scholarship" is the theme in which respondents most precisely articulate their ideas about the essence of "library as place" - even if, as appears to be the case, these ideas do not reflect the ways in which respondents actually use library space. The younger group that seems so greatly to value the physical library's conduciveness to scholarship is the same group that is much less likely than older groups to report having done graduate research or written part of the dissertation in the library; it is also the group that is least likely to report using a faculty study. Thus, the data cannot support the conclusion that "scholarly upbringing" - as characterized by the research and writing habits formed during graduate school-plays a formative role in shaping scholars' patterns of library use or their attitudes toward library space.

However, the data support the conclusion that, for this sample at the University of Oklahoma, younger scholars as a group value electronic resources more than older scholars, and they value the physical library's browsability and comprehensive- 
ness less than older scholars. These findings are not surprising, and they support the hypothesis. But, unexpectedly, younger scholars value the physical library's "conduciveness to scholarship" more than older scholars, even though their "scholarly upbringing" does not reflect this value. In addition, younger scholars overwhelmingly report spending the most time in the library, making both more visits and longer visits than older scholars.

This seems to indicate that the library building design trend toward including more space for library users and less space for library materials is exactly on target for younger faculty members as well as for students. Perhaps younger faculty members, like students fleeing the noisy dorm atmosphere, value the library space quite apart from its materials simply because it is a place to "escape," the only place where they can do sustained, focused intellectual work, free from the interruptions of departmental demands. If this is the case (and further research is needed to determine whether it is), then perhaps the debate about "deserted libraries" is moot. On the other hand, perhaps this means that the real issue is not whether academic libraries are deserted, but whether physical materials still matter.

\section{Notes}

1. Debra Engel and Karen Antell, "The Life of the Mind: A Study of Faculty Spaces in Academic Libraries," College \& Research Libraries 65 (Jan. 2004): 8-20.

2. Dixon Wector, "General Reading in a University Library," Harvard Library Bulletin 4 (1950): 5-15; Donald Coney, "The Future of Libraries in Academic Institutions," Harvard Library Bulletin 3 (Winter 1949): 327-31.

3. Scott Carlson, "The Deserted Library," Chronicle of Higher Education 48 (Nov. 16, 2001): A35.

4. Ibid.

5. John A. Shuler, "Ask Not for Whom the Bells Toll," Journal of Academic Librarianship 30 (Jan. 2004): 78; William H. Wisner, “Librarianship Enters the Twilight," Library Journal 126 (Jan. 2001): 68.

6. Scott Carlson, moderator, with Mary Reichel and Deanna B. Marcum, "Are College Libraries Too Empty?" [transcript of online discussion], Nov. 15, 2001, 2:00 p.m. (EST). [Accessed 15 December 2005]. Available online at http://chronicle.com/colloquylive/2001/11/empty/.

7. Thomas A. Horan, "The Paradox of Place," Communications of the ACM 44 (Mar. 2001): 58-60; Andrew Richard Albanese, “Deserted No More," Library Journal 128 (Apr. 15, 2003): 34-36; Gillian M. McCombs, “What Mighty Magic!" College EResearch Libraries 61 (July 2000): 296-98; Ellen D. Gilbert, "The High Tech and the Beautiful: Library Buildings, Digital Libraries, and the Future," Library Philosophy and Practice 3 (Fall 2000). [Accessed 15 December 2005]. Available online at http://libr.unl.edu:2000/LPP/gilbert2.htm; Michael Joyce, OtherMindedness (Ann Arbor: University of Michigan Press, 2000); Joseph C. Rizzo, "Finding Your Place in the Information Age Library," New Library World 103 (2002): 457-66.

8. Frieda Weise, "Being There: The Library as Place," Journal of the Medical Library Association 92 (2004): 9.

9. Walt Crawford, "Paper Persists: Why Physical Library Collections Still Matter," Online 22 (Jan. 1998): 42-48.

10. Larry Dowler, "Our Edifice at the Precipice," Library Journal 121 (Feb. 15, 1996): 118; Michael Gorman, "The Academic Library in the Year 2001: Dream or Nightmare or Something in Between?" Journal of Academic Librarianship 17 (Mar. 1991): 5; Walt Crawford and Michael Gorman, Future Libraries: Dreams, Madness \& Reality (Chicago: American Library Association, 1995): 118-19; Michael Gorman, The Enduring Library: Technology, Tradition and the Quest for Balance (Chicago: American Library Association, 2003): 4-5; William A. Gosling, "To Go or Not to Go? Library as Place," American Libraries 31 (Dec. 2000): 44-45.

11. Richard J. Bazillion and Connie L. Braun, Academic Libraries as High-Tech Gateways: A Guide to Design \& Space Decisions, 2nd ed. (Chicago: American Library Association, 2001): 37.

12. Alan Bundy, "Place of Connection: New Public and Academic Library Buildings in Australia and New Zealand," Australasian Public Libraries and Information Service 17 (March 2004): 32-47; Logan Ludwig, "Designing a Library: Everyone on the Same Page?" Bulletin of the Medical Library Association 89 (Apr. 2001): 204-11; Steven Foote, "An Architect's Perspective on Contemporary 
Academic Library Design," Bulletin of the Medical Library Association 83 (July 1995): 351-56.

13. Denise A. Troll, "How and Why Libraries are Changing: What We Know and What We Need to Know," Portal: Libraries and the Academy 2 (2002): 117-18.

14. Harold B. Shill and Shawn Tonner, "Creating a Better Place: Physical Improvements in Academic Libraries, 1995-2002," College \& Research Libraries 64 (Nov. 2003): 462.

15. Ibid, 431; Harold B. Shill and Shawn Tonner, "Does the Building Still Matter? Usage Patterns in New, Expanded, and Renovated Libraries, 1995-2002," College \& Research Libraries 65 (Mar. 2004): 148.

16. Sarah Lippincott and Martha Kyrillidou, "How ARL University Communities Access Information: Highlights from LibQUAL+ ${ }^{\text {TM }}$," ARL 236 (Oct. 2004): 8.

17. Engel and Antell, "The Life of the Mind," 18.

18. Ibid.

19. Association of Research Libraries, "A Webcast Introduction to LibQUAL+TM, Participant Questions" (Feb. 7, 2005). [Accessed 15 December 2005]. Available online at http://www.arl. org/training/webcast/libqualintro/questions.html; University of California, Irvine, "Summary of UCI Results and Next Actions," (no date). [Accessed 15 December 2005]. Available online at http://www.lib.uci.edu/libraries/new/archives/libqualresults.html.

20. Torkil Clemmensen, "Community Knowledge in an Emerging Online Professional Community: The Case of Sigchi.dk," Knowledge and Process Management 12, no. 1 (2005): 46; Helle Zinner Henriksen, Performance, Pressures, and Politics: Motivators for Adoption of Interorganizational Information Systems (Ph.D. dissertation, Department of Informatics, Copenhagen Business School, 2002): 51. [Accessed 15 December 2005]. Available online at http://www.hellezinnerhenriksen. info/data/hzh_phd.pdf.

21. This is similar but not identical to the results shown in figures 1 and 2 for "conduct research." The data for "conduct research" in figures 1 and 2 comes from survey question $2 \mathrm{~h}$, "Please indicate which of the following activities you engage in while visiting the library." The data for figures 6 and 7 , on the other hand, comes from survey question 16, "When you are working on a research project, do you conduct any of your research in the library?" (The survey is reproduced in the Appendix.) In essence, the former question asks, "When you are in the library, do you conduct research?" The latter question, conversely, asks, "When you are conducting research, do you do so in the library?"

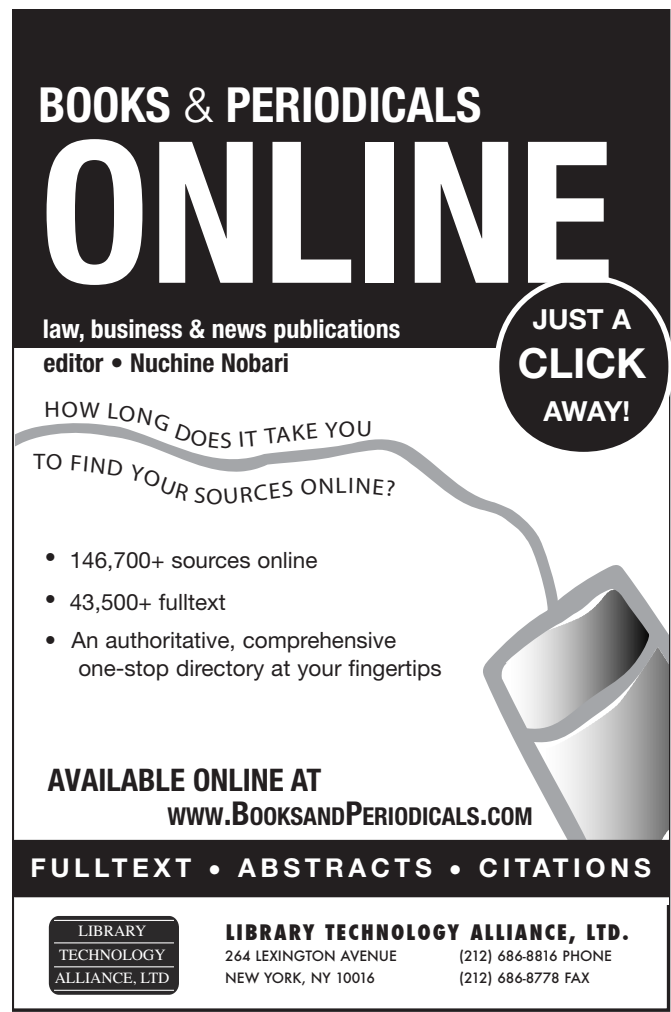




\section{APPENDIX \\ Survey of Scholars' Use of Academic Library Spaces}

\section{Part A. Demographics}

1. Your OU status is Faculty Doctoral student

2. In what college and department are you working today? (Please include both.) College Department

3. Which of the following best describes your primary area of research? (Check only one.)

_ Humanities (English, philosophy, languages, classics, etc.)

— Social sciences (history, psychology, sociology, political science)

_ Sciences and mathematics

_ Engineering

_ Business

- Education

Health sciences

—_ Professional schools (social work, library and information studies, law, journalism, etc.) 1

- Other (please specify) 1

4. In what year were you born?

Before 19301

— $1930-19391$

- $1940-19491$

— $1950-19591$

— $1960-19691$

— $1970-19791$

— 1980 or later 1

5. In what year did you earn your highest degree?

6. What is your gender? __ Male __ Female

7. How many hours per week do you typically spend on campus? (Check only one.)

_ More than 35 hours

25 - 35 hours

_Less than 25 hours

8. Please check the statement below that best describes your attitude toward emerging technology. (Check only one.)

_ I like technology. I like to be one of the first people to use new tools, resources and gadgets.

New technology can be useful, but I would rather not invest my time or money in new technologies until I feel reasonably certain that I will benefit from them.

_ I do not like to spend time or money on new technologies. I am usually one of the last people to learn to use the latest tools, resources, and gadgets. 


\section{Part B. Use of library space}

This part of the survey is about your use of OU Libraries' physical spaces.

OU Libraries comprises the following campus libraries and collections:

- Bizzell Memorial Library (including the main library plus four special collections: History of Science, Bass, Nichols, and Government Documents collections)

- Architecture Library (Gould Hall)

- Chemistry-Mathematics Library (Physical Sciences Building)

- Engineering Library (Felgar Hall)

- Fine Arts Library (Catlett Hall)

- Geology Library (Youngblood Energy Library, Sarkeys Building)

- Physics \& Astronomy Library (Nielsen Hall)

- Western History Collections (Monnet Hall)

As you answer the following questions, please think about the physical spaces in which these libraries and collections are housed, rather than the electronic resources available through OU Libraries' Web page.

For the purposes of this survey, "library visit" and "visit to the library" mean visits to the physical space of one of the OU Libraries, not a "virtual" visit to OU Libraries' electronic resources via the Web page.

1. Do you use OU Libraries' physical spaces? (Check only one.)

No. Please skip the remaining questions and submit the survey now. Yes. Please continue.

2. Please indicate which of the following activities you engage in while visiting the library. (Check all that apply)

\begin{tabular}{|l|l|l|}
\hline \multicolumn{2}{|l|}{ Yes } & No \\
\hline a. $\quad$ Checking out library materials & & \\
\hline b. Using photocopy machines & & \\
\hline c. Using microfilm/microfiche machines & & \\
\hline d. Visiting the coffee shop & & \\
\hline e. Using a library computer & & \\
\hline f. Using my faculty study or graduate student carrel & & \\
\hline g. Using library materials & & \\
\hline h. $\quad$ Conducting research & & \\
\hline i. $\quad$ Writing a paper & & \\
\hline j. $\quad$ Placing materials on reserve for courses & & \\
\hline k. Placing an interlibrary loan request & & \\
\hline 1. $\quad$ Consulting with a librarian or library staff & & \\
\hline m. Working with a group of students & & \\
\hline n. $\quad$ Teaching a class/attending a class & & \\
\hline o. $\quad$ Attending a library instruction class & & \\
\hline p. Working at a table/study carrel in the library & & \\
\hline q. Sitting in the lounge seating (sofas or easy chairs) & & \\
\hline r. $\quad$ Browsing new books & & \\
\hline s. $\quad$ Spending time in contemplation or sustained thinking & & \\
\hline t. $\quad$ Reading or browsing periodicals & & \\
\hline u. Sleeping & & \\
\hline v. Other: please specify: & & \\
\hline
\end{tabular}


3. Please indicate what possessions you bring to the library. (Check all that apply.)

\begin{tabular}{|l|l|l|}
\hline \multicolumn{2}{|l|}{ Yes } & No \\
\hline a. Laptop computer & & \\
\hline b. Cell phone & & \\
\hline c. Briefcase or backpack & & \\
\hline d. Personal copies of books or journals & & \\
\hline e. Library copies of books or journals & & \\
\hline f. Snacks and/or drinks & & \\
\hline g. Palm pilot or other personal digital assistant & & \\
\hline h. Writing materials (paper, pen or pencil) & & \\
\hline i. Other: please specify: & & \\
\hline
\end{tabular}

4. During the course of a typical semester, how frequently do you visit the library? (Check only one.)

$\begin{array}{ll}\text { _ } & 1-2 \text { times per semester } \\ - & 3-4 \text { times per semester } \\ - & 1-2 \text { times per month } \\ - & 3-4 \text { times per month } \\ - & 1-2 \text { times per week } \\ - & 3 \text { or more times per week }\end{array}$

5. In the past ten years, has the frequency of your visits ... (Check only one)

- Increased?

- Decreased?

_ $\quad$ Remained the same?

6. How long is your typical library visit? (Check only one.)

_ Under 30 minutes

- $30-60$ minutes

- $1-2$ hours

— more than 2 hours

7. In the past five years, has the length of your typical library visit... (Check only one)

- Increased?

- Decreased?

_ $\quad$ Remained the same?

8. Which libraries do you use? (Check all that apply.)

- Main library

— Branch libraries (Architecture, Chemistry-Mathematics, Engineering, Fine Arts, Geology, Physics-Astronomy)

_ Special collections (Western History Collection, History of Science Collections, Bass Collection, Nichols Collection, or Government Documents Collection)

9. Which library do you use most often? (Check only one.)

_ Main library

_ Branch Libraries (Architecture, Chemistry-Mathematics, Engineering, Fine Arts, Geology, Physics-Astronomy)

Special collections (Western History Collection, History of Science Collections, Bass Collection, Nichols Collection, or Government Documents Collection) 
10. Where do you sit in the library? (Check all that apply.)

Table with chairs

— Chair at a computer

_ Chair at a microfiche or microfilm reader

_ Study carrel

_ Lounge chair or sofa

_ Group study rooms

_ Faculty study

_ Coffee shop

— Other (please specify)

11. Do you ever visit the library just to study, work, or relax, without using library resources (such as books, journals, or library computers)? (Check only one.)

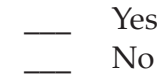

12. How did you learn to find your way around the library? (Check all that apply.)

_ I learned on my own through trial and error

_ I learned on my own by reading the maps and guides

_ I asked a staff member

— A classmate or colleague showed me around

_ I took part in a guided library tour

13. When you were a graduate student, did you have a graduate student carrel in a university library (at OU or elsewhere)? (Check only one.)

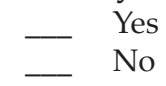

14. When you were working on your dissertation, did you do any of your research in the library? (Check only one.)

- Yes

- No

— I did not write a dissertation, or, I have not yet begun writing my dissertation.

15. Did you write any part of your dissertation in the library? (Check only one.)

- Yes

- No

— I did not write a dissertation, or, I have not yet begun writing my dissertation.

16. When you are working on a research project, do you conduct any of your research in the library? (Check only one.)

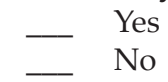

17. When you are writing a paper, article or book chapter, do you write any part of it in the library? (Check only one.)

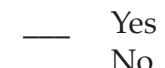


18. Do you use OU Libraries' electronic resources remotely? (This includes, for example, using online databases, e-journals, e-books, via the library Web site from your office or home.) (Check only one.)

- Yes 1

19. Please check the scenario below that most closely matches your typical library visit. (Check only one.)

The "targeted" visit. I look up the call numbers before I go to the library. I go to the stacks and get the materials I looked up. I check out the books or make photocopies of the journal articles. I leave the library.

1 The "exploring/browsing" visit. I go to library with a mental list of topics I need to look up. I look up call numbers, then go to the stacks to get the books. While I am there, I browse the shelves and gather additional materials. I might go back to the catalog to look up related topics. I sit down and look through all of books, choose some of them to check out. I check out and leave.

- The "what's new" visit. I go to the library to browse new materials in my subject area, look at the new book shelf, get a cup of coffee, browse the new journal issues in my subject area, and leave the library.

The "do it all" visit. I visit with the librarian, seek help from staff, put materials on hold, explore new books and journals in my subject area, check on my interlibrary loan requests, find out how to reserve materials for my course next semester, get a cup of coffee, and leave the library.

The "grading escape" visit. I go to the library with a stack of student papers to grade, a syllabus to work on for next semester, or other teaching-related tasks. I can do this kind of work faster in the library, because there are fewer interruptions than in my office.

The "research \& writing hideaway" visit. I go to the library for at least an hour or two to spend some uninterrupted time working on a paper-doing background reading, taking notes, or writing an outline or a draft.

The "collaboration" visit. I go to the library to meet with other people for pre-arranged study groups, appointments, or discussions.

Other. If none of the scenarios above match your typical library visit, please describe in one or two sentences:

20. Please mark " 1 ," " 2, " and " 3 " next to the three statements below that, in your opinion, represent the three most important functions of library space. (Mark only three, in ranked order, with " 1 " being the most important function, " 2 " being the second most important function, and " 3 " being the third most important function.)

The library is a place for reading, doing research, and writing

_ The library houses materials that I need

— The library is a social space

_ The library has public services desks where I can ask questions and interact with librarians and staff 1

The library is a place for quiet and solitude 1

The library is a place for collaboration 1 
21. In your opinion, are there differences between using the library remotely (using electronic resources via the Web site) and using the library's physical space? If so, what are the differences?

22. If you have any other observations about your use of library space that you would like to share, please use the space below. 